\title{
Steroid excretion and metabolism by gonadal tissue from a subject with testicular feminization syndrome
}

\author{
E. LOCKWOOD, P. C. GHOSH, G. W. PENNINGTON, AND R. TIPTON
}

From the Sheffield and Region Endocrine Investigation Centre, Jessop Hospital for Women, Sheffield

SYNOPSIS The initial clinical, pathological, and hormonal investigation of a patient with testicular feminization syndrome is described. Incubation of gonadal tissue with various radioactive substrates, together with the isolation and identification of the resulting metabolites, was demonstrated a high capacity to synthesize testosterone.

Two biosynthetic pathways were demonstrated, originating from progesterone and pregnenolone. These are essentially similar to those of the normal adult testes.

Low levels of activity were found in the phenolic fractions and no measurable production of oestrone, oestradiol, or oestriol was found.

\section{Case History and Clinical Report}

The patient was first seen at the Jessop Hospital for Women when aged 17 years, complaining of primary amenorrhoea. She was $5 \mathrm{ft} .9$ in. tall and excelled at athletics. On examination she had well developed breasts, scanty pubic hair, and no axillary hair. The external genitalia were those of a normal female. The vagina was 4 in. long and ended blindly. Pelvic organs were not palpable.

Past history revealed that when aged 10 weeks she had developed bilateral inguinal swellings. Bilateral inguinal herniorrhaphy had been performed. Normal looking 'ovaries' were described as having prolapsed into the hernial sacs and these had been replaced in the peritoneal cavity. The patient had no siblings and there was no history of other females in the family having primary amenorrhoea. A presumptive diagnosis of testicular feminization was made. This was confirmed by genetic studies. The buccal smear was chromatin negative and blood culture revealed a $46 \mathrm{XY}$ chromosome pattern-'normal male'. Subsequently the patient was seen yearly in the gynaecological clinics until she was 21 years. In view of the reported incidence of malignancy in the gonads in these cases, it was decided to admit the patient for gonadectomy. Preoperative hormonal studies were carried out and their

Received for publication 16 October 1973. results are shown in table I. The abdomen was opened through a low transverse incision. The gonads were situated on the lateral walls of the pelvis close to the internal inguinal rings. There was a well formed epididymis and gubernaculum, although there was no uterine tissue present. Both gonads were excised. Postoperative convalescence was uncomplicated. Six weeks after surgery, the patient was well but complained of 'flushes'. She suffered two to three flushes daily and was treated with ethinyloestradiol and megestrol acetate (Serial 28) as replacement therapy. This therapy was successful in eliminating the flushes, but was discontinued at the patient's request, as she was worried about weight gain.

\section{Histology (Dr A. S. Hill)}

Both gonads had a thick tunica albuginea, the main part of the gonadal tissue being soft and orangebrown in colour. Within this tissue in both gonads were firm, round nodules which could easily be separated from the surrounding tissue. Histologically both gonads were testes consisting of cords and tubules of varying size, surrounded by large numbers of interstitial cells. The tubules were composed of Sertoli cells, and did not appear to contain germ cells. They did not show the peripheral hyalinized zone common in undescended testicles. The discrete nodules had a similar histological appearance of tubules and interstitial cells, but the elements were 


\begin{tabular}{|c|c|c|c|c|c|c|c|c|c|c|c|}
\hline \multirow[t]{2}{*}{ Hormone } & \multicolumn{10}{|l|}{ Date } & \multirow{2}{*}{$\begin{array}{l}\text { Laboratory } \\
\text { Normal Range }\end{array}$} \\
\hline & $18 / 10 / 67$ & $19 / 10 / 67$ & $27 / 10 / 67$ & $728 / 10 / 67$ & $7 / 1 / 72$ & $8 / 1 / 72$ & $9 / 1 / 72$ & $15 / 1 / 72$ & $19 / 1 / 72$ & $18 / 2 / 72$ & \\
\hline $\begin{array}{l}17 \text { oxosteroids } \\
(\mathrm{mg} / 24 \mathrm{hr})\end{array}$ & - & - & $1 \cdot 0$ & $9 \cdot 1$ & $16 \cdot 6$ & $14 \cdot 7$ & $7 \cdot 1$ & - & - & $6 \cdot 0$ & $\begin{array}{l}\text { M } 5-24 \mathrm{mg} / 24 \mathrm{hr} \\
\text { F } 3-17 \mathrm{mg} / 24 \mathrm{hr}\end{array}$ \\
\hline $\begin{array}{l}\text { Adrosterone } \\
(\mathrm{mg} / 24 \mathrm{hr})\end{array}$ & - & - & - & 一 & $4 \cdot 55$ & $3 \cdot 28$ & 1.05 & - & - & $2 \cdot 53$ & $\begin{array}{l}\text { M } 2.5-5.5 \mathrm{mg} / 24 \mathrm{hr} \\
\text { F } 0.9-2.9 \mathrm{mg} / 24 \mathrm{hr}\end{array}$ \\
\hline $\begin{array}{l}\text { Aetiocholanolone } \\
(\mathrm{mg} / 24 \mathrm{hr})\end{array}$ & $\cdots$ & - & - & - & $5 \cdot 47$ & $3 \cdot 89$ & $1 \cdot 21$ & - & - & $3 \cdot 50$ & $\begin{array}{l}\text { M } 3 \cdot 5.8 .0 \mathrm{mg} / 24 \mathrm{hr} \\
\text { F } 0 \cdot 8.4 .8 \mathrm{mg} / 24 \mathrm{hr}\end{array}$ \\
\hline $\begin{array}{l}\text { Dehydroepiandrosterone } \\
\text { (mg/24 hr) }\end{array}$ & - & - & - & - & 0.72 & 0.51 & 0.41 & - & - & $0 \cdot 14$ & $\begin{array}{l}\text { M } 0 \cdot 5-4 \cdot 2 \mathrm{mg} / 24 \mathrm{hr} \\
\mathrm{F} 0 \cdot 5-1.7 \mathrm{mg} / 24 \mathrm{hr}\end{array}$ \\
\hline $\begin{array}{l}11 \text { oxo aetiocholanolone } \\
(\mathrm{mg} / 24 \mathrm{hr})\end{array}$ & - & - & 一 & - & $0 \cdot 32$ & 0.46 & $0 \cdot 11$ & $\frac{I}{ \pm}$ & - & - & $\begin{array}{l}\text { M } 0.3-1.4 \mathrm{mg} / 24 \mathrm{hr} \\
\text { F } 0 \cdot 2-1.0 \mathrm{mg} / 24 \mathrm{hr}\end{array}$ \\
\hline $\begin{array}{l}11 \text { hydroxyandrosterone } \\
(\mathrm{mg} / 24 \mathrm{hr})\end{array}$ & - & - & - & - & 0.61 & $1 \cdot 33$ & 0.30 & 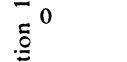 & - & - & $\begin{array}{l}\text { M } 0.1-1.0 \mathrm{mg} / 24 \mathrm{hr} \\
\text { F } 0.05-0.6 \mathrm{mg} / 24 \mathrm{hr}\end{array}$ \\
\hline $\begin{array}{l}11 \text { hydroxyaetiocholano- } \\
\text { lone }(\mathrm{mg} / 24 \mathrm{hr})\end{array}$ & - & - & - & - & 0.52 & 0.73 & 0.07 & 可- & - & - & $\begin{array}{l}\text { M } 0 \cdot 2-0.8 \mathrm{mg} / 24 \mathrm{hr} \\
\text { F } 0.01-0 \cdot 2 \mathrm{mg} / 24 \mathrm{hr}\end{array}$ \\
\hline $\begin{array}{l}17 \text { oxogenic steroids } \\
(\mathrm{mg} / 24 \mathrm{hr})\end{array}$ & - & - & $4 \cdot 9$ & $13 \cdot 3$ & $17 \cdot 8$ & $13 \cdot 3$ & $5 \cdot 2$ & $0_{-}$ & - & $12 \cdot 8$ & $\left.\begin{array}{l}M \\
F\end{array}\right\} 7-20 \mathrm{mg} / 24 \mathrm{hr}$ \\
\hline $\begin{array}{l}\text { Total oestrogens } \\
(\mu \mathrm{g} / 24 \mathrm{hr})\end{array}$ & $11 \cdot 0$ & 33.0 & 8.0 & $7 \cdot 0$ & $17 \cdot 8$ & $15 \cdot 1$ & $6 \cdot 0$ & $2 \cdot 2$ & $5 \cdot 6$ & $8 \cdot 9$ & $\begin{array}{l}\text { M } 10 \mu \mathrm{g} / 24 \mathrm{hr} \\
\text { F } 6-72 \mu \mathrm{g} / 24 \mathrm{hr}\end{array}$ \\
\hline $\begin{array}{l}\text { Follicle-stimulating } \\
\text { hormone (iu/24 hr) }\end{array}$ & - & - & - & - & 25 & 27 & 10 & - & - & 125 & $\begin{array}{l}\text { M } 2-15 \mathrm{iu} / 24 \mathrm{hr} \\
\text { F } 5-70 \mathrm{iu} / 24 \mathrm{hr}\end{array}$ \\
\hline $\begin{array}{l}\text { Luteinizing hormone } \\
\text { (iu/24 hr) }\end{array}$ & - & - & - & - & - & 56 & 18 & - & - & 90 & $\begin{array}{l}\text { M } 10-200 \mathrm{iu} / 24 \mathrm{hr} \\
\text { F } 8-300 \mathrm{iu} / 24 \mathrm{hr}\end{array}$ \\
\hline
\end{tabular}

Table I Hormonal excretion in a case of testicular feminization syndrome

more closely packed, with less intervening connective tissue. The vasa deferentia had complex mucosal folds and resembled Fallopian tubes.

\section{Hormonal Assays}

The hormonal assays carried out some years before operation, immediately preoperatively, and following operation are shown in table I. These demonstrate a low oxosteroid output in 1967 which had increased to normal range levels by 1972 . Postoperatively 17 oxosteroid excretion was in the low normal range.

It is of interest to note that the breakdown of 17 oxosteroids into the three main component fractions exhibited values more akin to the 'male' normal range. Oestrogen excretion appeared to be diminished following gonadectomy and, as might be expected, the pituitary gonadotrophin output appears to be increasing.

\section{Materials and Methods}

TISSUE

After removal from the abdominal cavity, the gonads were kept on ice. Part of the tissue was taken for histological examination and the remainder was stored at $-20^{\circ} \mathrm{C}$ until the time of the incubation studies (Kase and Morris, 1965). On thawing, the tissue was dissected free of fat and connective tissue and the main mass homogenized in $0.25 \mathrm{M}$ sucrose containing $0.001 \mathrm{M}$ EDTA. The lighter coloured nodules of tissue ('adenoma') which were distinct from the main mass of the tissue were homogenize separately. In each case a 1 in 10 homogenate was prepared.

\section{INCUBATION}

Radioactive steroids used as substrates in the incubation were obtained from the Radiochemical Centre, Amersham. Twenty or 30 nmoles of steroid substrate was incubated in $1 \mathrm{ml} 0.5 \mathrm{M}$ phosphate buffer, pH 7.4, containing $2 \mathrm{mM} \mathrm{MgCl}_{2}, 0.8 \mathrm{mM}$ NADP, $6 \mathrm{mM}$ glucose-6-phosphate, $1 \mathrm{mM}$ NAD, and 10 units glucose-6-phosphate dehydrogenase. After temperature equilibrium $1 \mathrm{ml}$ homogenate, equivalent to $100 \mathrm{mg}$ tissue, was added and incubated at $36^{\circ} \mathrm{C}$ for 30 minutes with constant shaking. The reaction was stopped by the addition of $0.1 \mathrm{ml}$ $\mathrm{HCl}$ and immediate storage at $-20^{\circ} \mathrm{C}$.

The following steroids were incubated: progesterone $-4-{ }^{14} \mathrm{C}, 20$ nmoles $(1.25 \mu \mathrm{Ci})$, pregnenolone $-7 \alpha-{ }^{3} \mathrm{H}, 20$ nmoles $(10 \mu \mathrm{Ci})$, androstenedione $-7 \alpha-{ }^{3} \mathrm{H}$, 20 nmoles $(10 \mu \mathrm{Ci})$ and dehydroepinadrosterone $-7 \alpha-{ }^{3} \mathrm{H}, 30$ nmoles $(10 \mu \mathrm{Ci}) .{ }^{14} \mathrm{C}$ progesterone and ${ }^{3} \mathrm{H}$, pregnenolone were incubated both separately and together. The 'nodular' tissue was incubated with ${ }^{14} \mathrm{C}$ progesterone.

ISOLATION AND IDENTIFICATION OF RADIOACTIVE METABOLITES

Steroid metabolites were extracted from the incuba- 
tion medium by adsorption on Arnberlite XAD-2 (Bradlow, 1968). The incubation medium was passed through a $1 \times 15 \mathrm{~cm}$ column and the steroids were eluted with $50 \mathrm{ml}$ methanol. Preliminary investigations had shown that $85-100 \%$ recovery of radioactive unconjugated steroids was achieved in this way. The methanol eluate was evaporated to dryness and the steroids taken up in $0.5 \mathrm{ml}$ methanol and left at $4^{\circ} \mathrm{C}$ for one hour to precipitate any remaining protein The radioactive metabolites were taken to dryness and partitioned between equal volumes of dichloromethane and $1.0 \mathrm{~N}$ sodium hydroxide to obtain neutral and phenolic fractions. The neutral fractions were analysed by paper and thin-layer chromatography. The isolation, identity, and radiochemical purity was achieved by at least two chromatographic systems, derivative formation, and recrystallization to constant specific activity. The initial chromatographic separation was carried out in the system ligroin : benzene/methanol : water (67:38/80:20)-PC system 1. Further separation and isolation of the steroid products involved the use of the paper system ligroin/methanol : water $(100 / 90$ : $10)$, the repeated use of PC system 1 , and the thinlayer systems benzene: ethyl acetate $(3: 1)$ and (90:10) after acetylation.

Corrections for losses at each chromatographic step. were assessed by measuring the recovery of authentic radioactive markers run at the same time.

Radioactive peaks on paper and thin-layer chromatographs were detected using a Packard radiochromatogram scanner (model 7201). Aliquots of the isolated steroids were counted in a Packard Tri-carb liquid scintillation spectrometer (model 3380).

\section{Results}

The radioactivity recovered in the neutral fractions from each incubation ranged from 48 to $79 \%$. Radioactivity in the phenolic fractions of incubations with ${ }^{3} \mathrm{H}$ dehydroepiandrosterone and ${ }^{3} \mathrm{H}$ androstenedione was not detected and was less than $0.2 \%$ in other incubations. The radioactivity of the isolated steroids is shown in table II and expressed as a percentage of the radioactivity originally present in the incubation. The values for oestrogens are given as the total radioactivity in the unpurified phenolic fractions. Also included in the table of results are values for an isolated but unidentified relatively non-polar steroid which was found to be present when ${ }^{14} \mathrm{C}$ progesterone and ${ }^{3} \mathrm{H}$ pregnenolone was incubated.

A group of polar steroids running close to the origin in the PC system 1 and unresolved after acetylation and thin-layer chromatography has been included in table II. Chromatographic mobilities suggest that 16-OH-progesterone and $19-\mathrm{OH}$ androstenedione are included in this group of steroids.

Approximately $90 \%$ of the added 20 nmoles ${ }^{14} \mathrm{C}$-progesterone was metabolized by the testicular tissue in $30 \mathrm{~min}$, the main individual product being 17-OH-progesterone. More than $10 \%$ was converted to testosterone. Rather less androstenedione $(1.27 \%)$ was isolated. The total possible oestrogen production was only $0.12 \%$. The metabolism of ${ }^{14} \mathrm{C}$ progesterone by the 'adenoma' tissue was identical to that of the testicular tissue.

Less than $2 \%$ of the 20 nmoles ${ }^{3} \mathrm{H}$-pregnenolone incubated with testis homogenate was recovered, indicating that the tissue has a greater capacity to utilize pregnenolone than progesterone, although the conversion to testosterone $(5 \cdot 27 \%)$ was only approximately half the amount formed from ${ }^{14} \mathrm{C}$ progesterone. However there was substantial conversion of pregnenolone to androstenediol (16.2\%) and DHA (3.95\%), and, since less $17-\mathrm{OH}$-pregnenolone than 17-OH-progesterone accumulated, it is suggested that side chain cleavage to $C_{19}$ steroids proceeds more readily from pregnenolone. This was substantiated when testicular tissue was incubated with ${ }^{14} \mathrm{C}$-progesterone and ${ }^{3} \mathrm{H}$ pregnenolone together, although in this case only $2.62 \%$ of the original ${ }^{14} \mathrm{C}$-progesterone was recovered whereas $5.05 \%{ }^{3} \mathrm{H}$ pregnenolone was unconverted.

More than $80 \%$ of ${ }^{3} \mathrm{H}$-DHA incubated with testicular tissue is metabolized, $7 \cdot 75 \%$ being converted to testosterone while $17.0 \%$ accumulated as androstenediol. Comparison of these values with the conversion of ${ }^{3} \mathrm{H}$-androstenedione to testosterone $(49.0 \%)$ indicated that the $3 \beta$ hydroxy dehydrogenase system is limiting in the conversion of $\mathrm{C}_{19}$ $3 \beta(\mathrm{OH})-\triangle^{5}$-steroids to androstenedione and testosterone. No oestrogen production was detected in the incubations of testicular tissue with either ${ }^{3} \mathrm{H}$-DHA or ${ }^{3} \mathrm{H}$-androstenedione.

Radioactivity recovered in the phenolic fractions, although very low, was investigated by running the appropriate fractions in the system benzene : ethenol (9:1). Oestrone, oestradiol, and oestriol markers were used. Small radioactive peaks corresponding to oestradiol were observed in the fractions from the incubations of testicular tissue with ${ }^{14} \mathrm{C}$-progesterone and ${ }^{14} \mathrm{C}$-progesterone with ${ }^{3} \mathrm{H}$-pregnenolone. The radioactive peaks were eluted and $10 \mathrm{mg}$ authentic oestradiol was added. On recrystallization, almost all counts were recovered in the mother liquor. There was thus no measurable production of oestrone, oestradiol, or oestriol during the incubation of the testicular tissue from any of the radioactive substrates used. 


\begin{tabular}{|c|c|c|c|c|}
\hline & & & & \\
\hline Testicular & "C progesterone & Testosterone & $3 \cdot 7$ & $9 \cdot 0$ \\
\hline & ${ }^{3} \mathrm{H}$ pregnenolone & 17-OH-progesterone & 0.45 & $16 \cdot 2$ \\
\hline & & Androstenediol & $20 \cdot 4$ & - \\
\hline & & Pregnenolone & $5 \cdot 05$ & - \\
\hline & & 17-OH-pregnenolone & $10 \cdot 4$ & - \\
\hline & & DHA & $7 \cdot 8$ & - \\
\hline & & Androstenedione & 0.7 & 1.07 \\
\hline & & Progesterone & 0.49 & $2 \cdot 62$ \\
\hline & & Non-polar steroid & $10 \cdot 4$ & 1.65 \\
\hline & & Polar fraction & - & $19 \cdot 0$ \\
\hline Testicular & ${ }^{3} \mathrm{H}$ DHA & Testosterone & $7 \cdot 75$ & \\
\hline & & Androstenediol & $17 \cdot 0$ & \\
\hline & & DHA & $15 \cdot 24$ & \\
\hline & & Androstenedione & 1.45 & \\
\hline & & Oestrogens & ND & \\
\hline Testicular & ${ }^{3} \mathrm{H}$ androstenedione & Testosterone & $49 \cdot 0$ & \\
\hline & & Androstenedione & $7 \cdot 4$ & \\
\hline & & Oestrogens & ND & \\
\hline ‘Adenoma' & ${ }^{14} \mathrm{C}$ progesterone & Testosterone & $10 \cdot 5$ & \\
\hline & & 17-OH-progesterone & $18 \cdot 5$ & \\
\hline & & 20-OH-progesterone & $0 \cdot 12$ & \\
\hline & & Androstenedione & 1.01 & \\
\hline & & Progesterone & $6 \cdot 1$ & \\
\hline & & Polar fraction & $23 \cdot 2$ & \\
\hline & & Non-polar steroid & 2.00 & \\
\hline & & Oestrogens & 0.07 & \\
\hline
\end{tabular}

Table II Conversion of radioactive substrates by testicular tissue

\section{Discussion}

The results of this study show that gonadal tissue from a patient with testicular feminization syndrome has a high capacity to synthesize testosterone from labelled precursors having the steroid nucleus, thus confirming the earlier findings of Griffiths, Grant, and White (1963); Morris and Mahesh (1963); David, Weiner, Ross, and Landau (1965); French, Baggett, Van Wyk, Talbert, Hubband, Johnston, Weaver, Forchielli, Rao, and Sarda (1965); Neher and Kahnt (1966); and Charreau and Villee (1968). Griffiths, Grant, and White (1963) also found very low levels of radioactivity (less than $1 \%$ ) in phenolic fractions and were unable to isolate any oestrogens. Kase and Morris (1965), however, isolated oestrone and oest- radiol from incubations with the three labelled precursors (pregnenolone, progesterone, and DHA); their conversions were small, in some instances only trace amounts could be detected. It is interesting $\frac{D}{O}$ to note that there was no conversion of androstenedione to oestrogen thus confirming the earlier $N$ observation of Wade, Wilkinson, Davis, and Jeffcoate (1968). French et al (1965), however, isolated small amounts of oestradiol 17-beta from testicular tissue incubated with ${ }^{14} \mathrm{C}$-progesterone and ${ }^{14} \mathrm{C}$ - testosterone and concluded that the source of plasma $Q$ and urinary oestrogens was the testicular tissue. In the present case, this seems unlikely. The patient studied by French et al (1965), however, was described as the 'incomplete form' of TFS.

The products isolated from each incubation study 
demonstrate two biosynthetic pathways to testosterone, the first from progesterone via $17-\mathrm{OH}$ progesterone and androstenedione, and the second via pregnenolone, 17-OH-pregnenolone, DHA and androstenediol. The biosynthetic pathway of testosterone production is thus similar to that of the normal adult testis (Axelrod, 1965). Mitzutani, Sonoda, Funuyama, Takemura, and Matsumoto (1972) have reported studies in vitro of testicular tissue from a subject with true hermaphroditism under similar incubation conditions. Their results show similar biosynthetic pathways with $60 \%$ conversion of ${ }^{14} \mathrm{C}$ progesterone and $70 \%$ conversion of ${ }^{3} \mathrm{H}$-pregnenolone. The tissue from the present study thus has a higher capacity to metabolize these precursors and to synthesize testosterone. It is not possible to determine if the testosterone-synthesizing capacity is greater or less than that of normal testicular tissue because of the absence of comparable studies of the normal tissue under the same incubation conditions.

Somerville (1973) has attempted to overcome this difficulty by studying experimental pseudohermaphroditism induced by the administration of the anti-androgenic compound cyproterone acetate (1,2 alpha-methylene-6-chloropregna-4,6-dione, 17 alpha-ol-3,20-dione) to pregnant rats and, to the newborn partially feminized offspring. The 'testes' of both normal and treated rats were incubated with various radioactive steroidal precursors, and following incubation and separation the end products examined. The results suggested that in the feminized rat testes the formation and side-chain cleavage of 17 alpha hydroxyprogesterone is less efficient than in the testes of the normal rats, but that as these enzymes are not involved in the formation of testosterone from androstenedione, testosterone is formed in high yields when the incubation is per- formed with androstenedione as substrate.

In general these experiments suggest that the capacity for testosterone synthesis in the testes of feminized rats is reduced, and a similar situation may be present in the human testes if control studies could be carried out.

\section{References}

Axelrod, L. R. (1965). Metabolic patterns of steroid biosynthesis in young and aged human testes. Biochim. biophys. Acta (Amst.), 97, 551 - 556.

Bradlow, H. L. (1968). Extraction of steroid conjugates with a neutral resin. Steroids, 11, 265-272.

Charreau, E., and Villee, C. A. (1968). Steroid metabolic pathways in feminizing testicular tissue. J. clin. Endocr., 28, 1741-1746.

David, R. R., Weiner, M., Ross, L., and Landau, R. L. (1965). Steroid metabolism in the syndrome of testicular feminization. J. clin. Endocr, 25, 1393-1402.

French, F. S. Baggett, B., Van Wyk, J. J., Talbert, L. M., Hubbard, W. R., Johnston, F. R., Weaver, R. P., Forchielli, E., Rao, G. S., and Sarda, I. R. (1965). Testicular feminization: clinical morphological and biochemical studies. J. clin. Endocr., 25 661-677.

Griffiths, K., Grant, J. K., and Whyte, W. G. (1963). Steroid biosynthesis in vitro by cryptorchid testes from a case of testicular feminization. J. clin. Endocr., 23, 1044-1055.

Kase, N., and Morris, J. M. (1965). Steroid synthesis in the cryptorchid testes of three cases of the "testicular feminization' syndrome. Amer. J. Obstet. Gynec., 91, 102-105.

Mizutani, S., Sonoda, T., Furuyama, J., Takemura, M., and Matsumoto, K. (1972). Steroid biosynthesis in vitro by gonadal tissue in true hermaphroditism. Acta endccr. (Kbh.), 69, 119. 126.

Morris, J. M., and Mahesh, V. B. (1963). Further observations on the syndrome, 'testicular feminization'. Amer. J. Obstet. Gynec., 87, $731-748$.

Neher, R. and Kahnt, F. W. (1966). Gonadal steroid biosynthesis in vitro in four cases of testicular feminization. In Androgens in Normal and Pathological Conditions (Excerpta Medica International Congress Series, No. 101), edited by A. Vermeulen, pp. 130-136. Excerpta Medica Foundation, Amsterdam.

Sommerville, I. F. (1973). Recent advances in the endocrinology of intersexuality. In Adolescentology, edited by C. J. Dewhurst and M. De Negri, pp. 94-105. Carlo Erba Foundation, Milan.

Wade, A. P., Wilkinson, G. S., Davis, J. C., and Jeffcoate, T. N. A. (1968). The metabolism of testosterone, androstenedione and oestrone by testes from a case of testicular feminization. $J$. Endocr., 42, 391-403. 